Review Article

Open Access

\title{
Effect of Roasting and Dehulling on Antioxidant activity, Oil quality and Protein functionality of Sesame Seeds used in Tahina and Halawa
}

\author{
Khalid Al-Ismail ${ }^{\star}$, Alawamleh $\mathbf{N}$ and Al-Dabbas $\mathbf{M}$ \\ Department of Nutrition and Food Technology, Faculty of Agriculture, The University of Jordan, Jordan
}

\section{Article Info}

*Corresponding author:
Khalid Al-Ismail
Department of Nutrition and Food
Technology
Faculty of Agriculture
The University of Jordan
Jordan
E-mail: kh.ismail@ju.edu.jo

Received: April 29, 2018

Accepted: May 9, 2018

Published: May 15, 2018

Citation: Al-Ismail K, Alawamleh N, Al-Dabbas M. Effect of Roasting and Dehulling on Antioxidant activity, Oil quality and Protein functionality of Sesame Seeds used in Tahina and Halawa. Madridge J Food Technol. 2018; 3(1): 108-113.

doi: $10.18689 / \mathrm{mjft}-1000116$

Copyright: ( $\subset 2018$ The Author(s). This work is licensed under a Creative Commons Attribution 4.0 International License, which permits unrestricted use, distribution, and reproduction in any medium, provided the original work is properly cited.

Published by Madridge Publishers

\begin{abstract}
The aims of this study were to evaluate the effect of roasting and dehulling on the antioxidant activity and some of protein functionalities of sesame seeds used in tahina and halawa production. Samples were taken throughout tahina and halawa production steps. Seed dehulling and roasting resulted in a $30 \%$ reduction in total phenol content (TPC). The production steps of tahini and halawa increased TPC by about $61 \%$ and $108 \%$, respectively. Although Tahina and Halawa had higher TPC than dehulled and roasted seeds they showed lower DPPH scavenging activity. The $\mathrm{IC}_{50}$ for tahina and halawa was about $40-50 \%$ greater than those of dehulled and roasted. Proteins isolated from dehulled seeds showed greater emulsion capacity (EC) and stability (ES) than protein from roasted seeds except at $\mathrm{pH} 2$ where roasted protein showed greater EC and ES. Roasted seeds' protein showed greater water and oil absorption capacities than that of dehulled protein.
\end{abstract}

Keywords: Antioxidant activity; Tahina and halawa; Roasted seeds; Emulsion capacity (EC).

\section{Introduction}

Sesame seed (Sesamum indicum .L) has been considered as one of the most important and healthful crops in the world for many years. It is renowned as a nutritious food for human health and is used as an ingredient in sweets and confectionaries [1]. Sesame spots, cakes, and seeds exhibit high reducing power and free radical scavenging activity as well as protection against oxidative deterioration. Sesame seeds provide highly stable oil, nutritious protein and meals [2] and have various beneficial health properties, including hypocholesterolaemic, hepatoprotective, and antimutagenic effects [3-5]. In the Middle East, dehulled sesame seeds are used primarily in the production of tahini which is made from a paste of dehulled roasted sesame seeds and halawa and is similar to peanut butter. The dehulling and roasting procedure may change the antioxidant activity, oil quality and protein functional properties of the dehulled sesame. These changes may affect positively or negatively the food products prepared from dehulled and roasted sesame such as tahina and halawa.

Sesame seed is an important source of oil (44-58\%), protein (18-25\%), carbohydrate $(\sim 13.5 \%)$ and ash ( $5 \%)$. The oil fraction is remarkably stabile to oxidation which can be attributed to endogenous antioxidants, namely lignins and tocopherols [6,7]. Recent studies indicate sesame protein is an excellent quality protein (nearly $80 \% \alpha$-globulin and $20 \% \beta$-globulin) with high nutritional and biological (high netprotein utilization and digestibility) [8]. Sesame proteins have been classified in four classes of protein based on Osborne sequential extraction and different solubility: water soluble albumins, salt 
soluble globulins, prolamins soluble in alcohol/water mixtures and glutelins soluble in dilute acid or alkali. Rivas [9] reported that the proteins in sesame flour consisted of $8.6 \%$ albumin, $67.3 \%$ globulin, $1.4 \%$ prolamin and $6.9 \%$ glutelin. Furthermore, they reported that the alkali protein isolate (extracted in water at $\mathrm{pH} 10$ and precipitated at $\mathrm{pH} 4.0$ ) were comprised of $41.3 \%$ albumin, $14.8 \%$ globulin, $0.8 \%$ prolamin, $41.0 \%$ glutamine. Onsaard et al. [10]; Zhao [5] who found that water- and oilholding capacities of roasted sesame seeds meal protein ranged from 1.29 to $3.30 \mathrm{gm}$ water/ gm protein and from 1.19 to $3.08 \mathrm{~g}$ oil/ $\mathrm{g}$. Maximum emulsifying activity of sesame seed meal protein (83\%) was obtained at a $\mathrm{pH}$ of 10 . Emulsifying activity decreased with increasing $\mathrm{pH}$ reaching the minimum value $(37 \%)$ at $\mathrm{pH} 6.0$; increasing $\mathrm{pH}$ to more than 6.0 increased emulsifying activity [5]. Minimum emulsion stability of native sesame seed meal protein was recorded at $\mathrm{pH} 4$ (42.86\%), followed by subsequent increase in emulsion stability as the $\mathrm{pH}$ increased. The maximum emulsion stability of sesame seed meal protein $(86.75 \%)$ was obtained at $\mathrm{pH} 10$ [5]. To the best of our knowledge, there is little or no data on the effect of roasting and dehulling of sesame seed on antioxidant activity and protein functionality, therefore, the objectives of this study were to evaluate the effects of processing of tahina and halawa on the polyphenol content and its antioxidant activity, the effects of roasting on functional properties of protein, and the effects of roasting on oil quality.

\section{Materials and Methods}

\section{Sample collection}

Ethiopians sesame seeds Sesamum indicum. $L$ (about $3 \mathrm{~kg}$ ) were purchased from two (Jordanian local producer).

\section{Steps of Sesame paste (Tahina) and Halawa processing}

The production of Tahina and Halawa include the following steps (Figure 1):

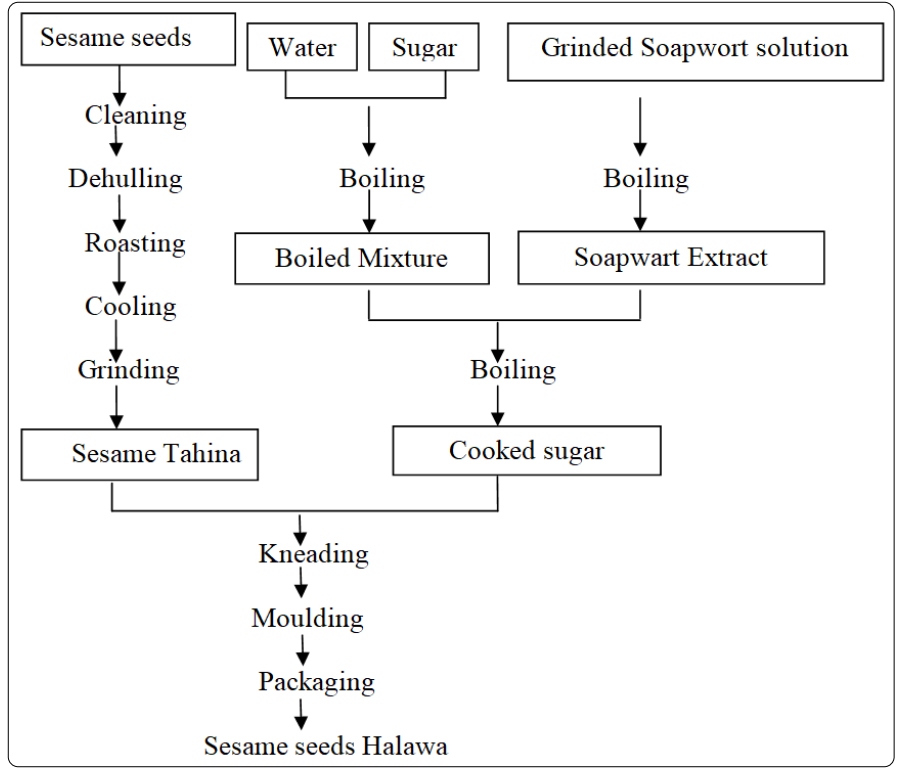

Figure1. Flow chart for Tahina and Halawa processing steps

1-Raw sesame seeds were sieved to remove stones and soil.

2-Seeds dehulling: The first producer dehulled seeds by soaking seeds in a concentrated salt solution (14-18\%) for 2 hours. Hulls were floated to the surface then removed. The second producer dehulled seeds using a peeling machine.

3- Seeds roasting: The first producer roasted seeds at $130^{\circ} \mathrm{C}$ in a steam heated oven for two hours with shaking. The second producer roasted seeds under pressure ( 5 bar) at an oven temperature of $130^{\circ} \mathrm{C}$ using six rotating cylindrical tanks that are heated electrically.

4-Tahina production: Tahina production (by both producers) was carried out by grinding and mixing the roasted seeds using two stones wheels, one of them fixed, the other with continuous rotation until to obtain sesame paste $(2 \mathrm{rpm}$ for 1-2 $\min )$.

5- Production of Halawa: Halawa production (by both producers) included mixing of Soapwarte (Saponaria officinalis) water extract (1\%) with sucrose solution containing citric acids then cooking at $130^{\circ} \mathrm{C}$ for $45-60 \mathrm{~min}$. The cooked mixture (natef) was added to tahina past (1:1) in a kneading tank and mixed until a homogenous mixture was obtained (15 $\min )$.

\section{Preparation of raw, dehulled, roasted sesames seeds, tahina and halawa extracts}

Two grams each of fresh, dehulled and roasted sesame seeds, and $10 \mathrm{~g}$ of tahina and halawa were suspended in $100 \mathrm{ml}$ of $90 \%$ ethanol with continuous shaking for two hours at room temperature. The extract was then filtered and stored at $4^{\circ} \mathrm{C}$ until analysis [11].

\section{Determination of total phenolic content}

The total phenolic contents of the extracts were determined according to the method Kaur and Kapoor [12]. Extract $(300 \mu \mathrm{l})$ was transferred into a $10 \mathrm{ml}$ volumetric flask, $3 \mathrm{ml}$ of $\mathrm{Na}_{2} \mathrm{CO}_{3}(20 \% \mathrm{w} / \mathrm{v})$ were added and shaken by hand for $3 \mathrm{~min}$. Folin Caleuclitea reagent (FCR; $0.5 \mathrm{ml}$ ) was added and the volume was made up to $10 \mathrm{ml}$ with distilled water. The solution was allowed to stand at room temperature in the dark for one hour before absorbance was measured at 750 nm using UV/ visible spectrophotometer (Model UVD-2950, Labomed, Inc). Total phenolic content was expressed as mg gallic acid equivalent/kg seeds.

\section{Scavenging ability of the extracts on the 2,2-diphenyl-1- picrylhydrazyl radical}

The 2,2-diphenyl-1-picrylhydrazyl (DPPH) scavenging ability of the extracts of sesame seeds and its products was measured according to method of Hatano et al. [13]. An aliquot $(1 \mathrm{ml})$ of each extract at different concentrations was added to $0.25 \mathrm{~mL}$ of $0.2 \mathrm{mmol} / \mathrm{L}$ DPPH methanolic solution in $5 \mathrm{ml}$ test tubes. Absorbance was measured at $517 \mathrm{~nm}$ after 30 minutes of storage in the dark using a UV/visible spectrophotometer (Model UVD-2950, Labomed, Inc). The antiradical activity was expressed as IC50 (mg/mL) which is the concentration required to cause a $50 \%$ inhibition. The scavenging activity of the extracts was calculated as follows:

Inhibition $\%$ = Abs control - Abs sample/Abs control*100\% 


\section{Oil extraction from sesame seeds}

Ground seeds were soaked in petroleum ether for 24 hours then solvent was decanted and defatted ground seeds were air dried at room temperature for about 24 hour to remove residual solvent. The process was repeated twice. The oil obtained was kept at $-18^{\circ} \mathrm{C}$ until analysis.

\section{Preparation of protein isolate from sesame seeds}

Protein isolate fromfresh raw, and roasted dehulled sesame seeds was prepared according to the method of Sosulski and Mccurdy [14]. The defatted (raw, dehulled and roasted seeds) were dispersed in water then $\mathrm{pH}$ was adjusted to 10 using $0.1 \mathrm{~N} \mathrm{NaOH}$ for 1 hour with continuous stirring followed by centrifugation (centrifuge $5810 \mathrm{R}$; EPPENDORF, Germany) at $3800 \mathrm{rpm}$ for 30 minutes at $4^{\circ} \mathrm{C}$. The process was repeated twice. The $\mathrm{pH}$ of the combined supernatant was adjusted to the isoelectric point PI (pH4-5) with $0.2 \mathrm{~N} \mathrm{HCL}$. The mixture was centrifuged at $3800 \mathrm{rpm}$ for 30 minutes at $4^{\circ} \mathrm{C}$. Precipitated protein was then washed with distilled water and $\mathrm{pH}$ was adjusted to 7 using $0.2 \mathrm{~N} \mathrm{NaOH}$. Protein isolate was then freeze dried using Freeze dryer (GPERGN, model FDB-5502, Gmopo-city, Korea).

\section{Emulsion capacity and stability of sesame seeds protein isolates}

Emulsification capacity of proteins (raw and roasted sesame) was evaluated according to the method of Marshal [15]. One gram of sample was whipped with $100 \mathrm{ml}$ of distilled water at $\mathrm{pH} 2,4,6,8$, and 10 adjusted using $0.1 \mathrm{M} \mathrm{HCL}$ or 0.1 $\mathrm{M} \mathrm{NaOH}$ then titrated with corn oil to the break point (separation of emulsion into two phases) of the emulsion using a blender at low speed. Emulsion capacity (EC) was expressed as grams of oil emulsified per gram of sample before phase inversion. Emulsions were transferred into 250 $\mathrm{ml}$ graduated cylinders and emulsion stability was recorded after 1, 3, 24 and $48 \mathrm{hr}$ at room temperature by measuring the amount of water separated from the oil.

\section{Oil and water absorption capacity}

For oil and water absorption capacity determinations (raw and roasted sesame protein), the method of Beuchat [16] was followed. One gram of sample was mixed with $10 \mathrm{ml}$ of corn oil (purchased from local market) or distilled water for 30 seconds in a $25-\mathrm{ml}$ centrifuge tube. Samples were allowed to stand at room temperature for 30 minutes then centrifuged at 3000 rpm for 30 min (Hettich Zentrifugen., model Universal 32 , UK). The volume of the supernatant was measured in a 10 $\mathrm{ml}$ graduated cylinder. Results were expressed as milliliters of corn oil or water absorbed per gram of sample.

\section{Quality evaluation of the dehulled and roasted sesame seeds oils}

The quality of the dehulled and roasted sesame seeds oils was evaluated by free fatty acids and peroxide value test according the AOAC standard methods [17-19].

\section{Statistical Analysis}

For phenol content and free radical scavenging activity, all assessments were carried out in triplicate while for those of functional properties proteins of sesame seed were carried out in duplicate [20-22]. The design followed in experiment is complete randomized (CRD). Analysis of variance (ANOVA) was performed using Statistical Analysis Software [23]. Differences among the mean values were tested using Least Significant Difference (LSD).

\section{Results and Discusions}

\section{Total Polyphenol Contents (TPC)}

The difference in total polyphenols content (TPC) of the products of the various production steps followed by the two producers lies in the dehulling and roasting steps. Dehulling was carried out by the first producer by soaking seeds in salt solution, while the second producer used a peeler machine which is based on friction. Roasting was done by first producer using a mechanical oven at $130^{\circ} \mathrm{C}$ for 2 hours, while second producer roasted under pressure (5bar) at $130^{\circ} \mathrm{C}$ using six rotating cylindrical tanks. Raw seed samples from both producers had similar TPC, which may be due to the fact that the source of these seeds was Ethiopia. The TPC of these seeds were slightly lower than those of Rizki et al. [24] who reported that the content of these compounds extracted with $80 \%$ ethanol was $370 \mathrm{mg} / \mathrm{kg}$. It is evident from data in table 1 that the TPC of the two producers showed a significant decrease after dehulling by about $18 \%$ for the first producer and $10 \%$ for the second. This indicates that the hulls may contain significant amounts of polyphenols. Roasting dehulled seeds negatively affected polyphenol content; TPC content decreased significantly ( $p \leq 0.05$ ) after 2 hrs of roasting at $130^{\circ} \mathrm{C}$ by about $12.5 \%$ compared to dehulled seeds. This finding agrees with that of Rizki et al. [24] who reported that TPC decreased in sesame seeds roasted by microwave. Riziki [25] reported that roasting sesame seeds at $150^{\circ} \mathrm{C}$ for up to 90 min significantly increased the TPC but then decreased it toward the end of roasting period (360 min). They attributed the increase in TPC to production of Maillard reaction products generated during roasting which can be measured by Folin-Ciocalteu reagent. The amount of TPC in tahina of the two producers was about twice that of the dehulled sesame seeds. The increase in TPC in tahina could be due to the severe mixing during processing which ruptures seed cells releasing more polyphenols extractable by the solvent used in this study. The amount of TPC in halawa was about 2.5 times that in the dehulled seeds. This increase could also be due to the severe mixing of the seeds and to polyphenols from the wart root extracts (soap root) which was added as an emulsifier. This increase could also be due to Maillard reactions. The results shown in table 1 indicate that there were significant ( $p \leq 0.05$ ) effect of the processors on TPC. The TPCs of the dehulled, roasted, tahina and halawa produced by the second processor were significantly higher than those produced by the first processor. 
Table 1. Influence of Production Steps of Tahina and Halawa on Polyphenols

\begin{tabular}{|l|l|l|}
\hline \multirow{2}{*}{ Treatment } & \multicolumn{2}{|c|}{ Polyphenols $(\mathrm{mg} / \mathrm{kg})$} \\
\cline { 2 - 3 } & First Producers & Second producers \\
\hline Raw & A440 $\pm 13 \mathrm{c}$ & $\mathrm{A} 412 \pm 7 \mathrm{c}$ \\
Dehulled & $\mathrm{A} 359 \pm 4 \mathrm{c}$ & $\mathrm{A} 372 \pm 8 \mathrm{c}$ \\
Roasted & A314 $\pm 8 \mathrm{c}$ & A330 $\pm 6 \mathrm{c}$ \\
Tahina & B680 $\pm 20^{\mathrm{b}}$ & A735 $\pm 18 \mathrm{~b}$ \\
Halawa & B827 $\pm 11^{\mathrm{a}}$ & A1012 $\pm 23^{\mathrm{a}}$ \\
\hline
\end{tabular}

-Values within the same row with different capital letters are significantly different $(p \leq 0.05)$.

-Values within the same column with different lower case letters are significantly different $(p \leq 0.05)$.

\section{Effect of processing steps on the antioxidant activity}

The antioxidant activities of the extracts of sesame seeds products in this study were evaluated using DPPH radical. This radical is commonly used for the assessment of antioxidant activity in vitro. DPPH is a very stable organic free radical with a deep violet color, with an absorption maximum in the 515-528 $\mathrm{nm}$ range. Upon receiving a proton from a hydrogen donor, mainly from phenolics, it loses it chromophore and becomes yellow. As the concentration of phenolic compounds or degree of hydroxylation of the phenolic compounds increases, the DPPH radical scavenging activity (antioxidant activity) also increases [26]. Because these radicals are very sensitive to the presence of hydrogen donors, the system operates at very low concentrations. Therefore, a large number of samples can be tested in a short time. Data in table 2 shows that processing steps had significant effect on the antioxidant activity of their product extracts. Although, tahina and halawa extracts had the highest TPC, they showed the lowest antioxidant. For example, the phenolics required to scavenge $50 \%$ of DPPH radicals from dehulled seeds extracts were 9.8 and $18 \mu \mathrm{g}$, and 18.8 and $33.3 \mu \mathrm{g}$ for tahina extracts from the first and second producers, respectively. This could be due to the change in phenolic structure or to the chelating effect of their component of minerals. In both cases, the compound activity might be decreased.

Table 2. IC $C_{50}$ Phenolic content $(\mu \mathrm{g})$ causing $50 \%$ inhibition of DPPH

\begin{tabular}{|l|l|l|}
\hline Sample & First Producer & Second Producer \\
\hline Dehulled & $B 9.80 \pm 1.4 \mathrm{c}$ & A18.0c \\
Roasted & B11.8 $\pm 1.3 \mathrm{c}$ & A15.7d \\
Halawa & B15.8 $\pm 1.5 \mathrm{~b}$ & A24.0b \\
Tahina & B18.0 $\pm 1.6 \mathrm{a}$ & A33.3a \\
\hline
\end{tabular}

-Values within the same row with different capital letters are significantly different $(p \leq 0.05)$.

-Values within the same column with different small letters are significantly different $(p \leq 0.05)$.

\section{Water and Oil Absorption Capacity}

Data in table 3 shows that no significant effect of producers on the water absorption capacity or oil absorption capacity. Roasting had a slight but significant $(P \leq 0.05)$ effect on water holding capacity. The increase in water absorption by the roasted seeds was about $32.55 \%$ when compared to that of raw dehulled seeds. These results may be due to protein unfolding during roasting which exposed hydrophilic amino acids which bind water.

Oil absorption capacity depends on several factors such as type and source of protein, protein particle size and whether or not it is subjected to heat treatment. As shown in table 3, oil absorption capacity for the raw dehulled sesame seeds was about $1.2 \mathrm{~g} / \mathrm{g}$ protein, similar to that reported by Kanu [27]. However, these results disagree with those of Zhao [5] who reported higher oil holding capacity of sesame protein isolate $(2.7 \mathrm{~g} / \mathrm{g}$ protein), which might be due to the type and source of sesame seeds and to the method of protein extraction. However, roasting at $130^{\circ} \mathrm{C}$ for 2 hours increased the oil holding capacity by about 2 fold. These results could be due to the partial denaturation of proteins with exposition of hydrophobic amino acid groups during roasting. The presence of several non-polar side chains may bind the hydrocarbon chains of fats, thereby increasing absorption of oil. Results in table 3 indicate that the raw dehulled sesame seed exhibited lower oil holding capacity than water holding capacity.

Table 3. Water and oil holding capacity* of the isolated proteins of dehulled and roasted sesame seeds at $130^{\circ} \mathrm{C}$ for $2 \mathrm{hrs}$.

\begin{tabular}{|l|l|l|c|c|}
\hline \multirow{2}{*}{ Parameter } & \multicolumn{2}{|c|}{ First Processor } & \multicolumn{2}{c|}{ Second Processor } \\
\cline { 2 - 5 } & Dehulled & Roasted & Dehulled & Roasted \\
\hline $\begin{array}{l}\text { Water absorption capacity } \\
\text { (g water/g protein }\end{array}$ & $2.0 \pm 0.1 \mathrm{~b}$ & $2.6 \pm 0.2 \mathrm{a}$ & $1.9 \pm 0.2^{\mathrm{b}}$ & $2.8 \pm 0.1 \mathrm{a}$ \\
\hline $\begin{array}{l}\text { Oil absorption capacity } \\
\text { (g oil/g protein }\end{array}$ & $1.1 \pm 0.1 \mathrm{~b}$ & $2.8 \pm 0.1 \mathrm{a}$ & $1.3 \pm 0.2^{\mathrm{b}}$ & $2.9 \pm 0.2 \mathrm{a}$ \\
\hline
\end{tabular}

-*Measured as volume $(\mathrm{ml})$ of oil or water absorbed per one gram of protein.

-Values within the same row with different letters are significantly different $(p \leq 0.05)$.

\section{Emulsion capacity (EC)}

The effects of $\mathrm{pH}$ on the emulsifying capacity (EC) of dehulled and roasted sesame seeds from the two producers are shown in table 4. As shown in table 5, no significant effect occurred due to the producers on the emulsion capacity (EC) of the dehulled and roasted seeds. The minimum emulsion capacities of dehulled and roasted sesame seeds from the two producers at $\mathrm{pH} 4$ (near isoelectric point) were 20 and 10 $\mathrm{ml}$ oil/g protein, respectively. This is due to the fact that at the pl of protein, the net charge is zero which enhances proteinprotein interaction. Therefore, protein precipitate and will not be able to migrate to protein oil interface leading to minimum $\mathrm{EC}$ at this $\mathrm{pH}$ [28]. These results agree with those of Kanu et al. [27] and Khalid et al. [29]. These results partially agree with those of Zhao et al. [5] who reported that EC for roasted sesame seed protein was minimal at $\mathrm{pH}$ 2-7 range and these $\mathrm{EC}$ were not significantly different.

Table 4. Emulsion capacity* at different $\mathrm{pHs}$ for the isolated proteins of dehulled and roasted sesame seeds at $130^{\circ} \mathrm{C}$ for $2 \mathrm{hrs}$.

\begin{tabular}{|c|c|c|c|c|}
\hline \multirow{2}{*}{$\mathrm{pH}$} & \multicolumn{2}{|c|}{ First Producers } & \multicolumn{2}{c|}{ Second producers } \\
\cline { 2 - 5 } & Dehulled & Roasted & Dehulled & Roasted \\
\hline 2 & $150^{\mathrm{b}}$ & $200^{\mathrm{a}}$ & $150^{\mathrm{b}}$ & $200^{\mathrm{a}}$ \\
4 & $20^{\mathrm{d}}$ & $10^{\mathrm{d}}$ & $20^{\mathrm{d}}$ & $10^{\mathrm{d}}$ \\
6 & $50^{\mathrm{c}}$ & $40^{\mathrm{c}}$ & $50^{\mathrm{c}}$ & $40^{\mathrm{c}}$ \\
8 & $150^{\mathrm{b}}$ & $100 \mathrm{~b}$ & $150^{\mathrm{b}}$ & $100^{\mathrm{b}}$ \\
10 & $170^{\mathrm{a}}$ & $120 \mathrm{~b}$ & $170^{\mathrm{a}}$ & $120 \mathrm{~b}$ \\
\hline
\end{tabular}

-*Emulsion capacity expressed as amount of oil $(\mathrm{ml})$ absorbed per gram of protein.

-Values are the means of two replicates $\pm S D$.

-Values within the same column with different letters are significantly different $(p \leq 0.05)$. 
A higher EC was observed on both sides of the isoelectric point for the raw dehulled and roasted sesame seeds proteins. At $\mathrm{pH} 2$, ECs of $150 \mathrm{ml}$ oil/g protein for raw and $200 \mathrm{ml} \mathrm{oil} / \mathrm{g}$ protein for roasted proteins was found. This indicates that roasting had a positive effect on EC of sesame seed protein. The $\mathrm{EC}$ for roasted protein at $\mathrm{pH} 2$ was 1.33 times greater than that of raw protein. The emulsion produced by roasted protein at this $\mathrm{pH}$ was very thick and similar to that of mayonnaise. Further studies are needed to explain this behavior. The highest EC for the raw dehulled seed protein occurred at $\mathrm{pH}$ $10(170 \mathrm{ml} / 1 \mathrm{~g}$ protein). These results agree with those of Kanu et al. [27] and Khalid et al. [29]. The roasted sesame seed protein showed similar behavior to that of raw dehulled protein. As shown in table 4, roasting significantly decreased the $\mathrm{EC}$ at all $\mathrm{pH}$ values tested except at $\mathrm{pH} 2$ where it increased. For example, at pH 10, EC decreased about $30 \%$ compared to that found for dehulled protein. These results indicate that emulsion capacity was $\mathrm{pH}$-dependent and that alkaline $\mathrm{pH}$ was found to improve the emulsion capacity more than acidic $\mathrm{pH}$.

\section{Emulsion stability (ES)}

The effects of $\mathrm{pH}$ on emulsion stability (ES) of the dehulled sesame protein isolate were similar to the effects of $\mathrm{pH}$ on protein emulsion capacity (Table 5 ). The minimum ES was in the $\mathrm{pH}$ range of 4-6 increasing on both sides of this range reaching maximum values at $\mathrm{pH} \mathrm{2,8}$ and 10. At these $\mathrm{pH}$ values, no separation of liquid was observed after storage at room temperature for $48 \mathrm{hrs}$.

On the other hand, roasting of sesame seeds had a negative effect on the ES at all $\mathrm{pH}$ values except at $\mathrm{pH} 2$. The stability was minimal at $\mathrm{pH} 10$ and then at $\mathrm{pH}$ 8. This behavior could be due to the decrease in the forces responsible for the formation of a strong viscoleastic film at the interface which results in lower stability of the formed emulsion.

Table 5. Emulsion stability* of raw and roasted sesame seeds protein isolate at different $\mathrm{pH}$ values for the two producers.

\begin{tabular}{|c|c|c|c|c|c|c|c|c|c|c|c|c|c|c|c|c|}
\hline & \multicolumn{8}{|c|}{ First Producer } & \multicolumn{8}{|c|}{ Second producers } \\
\hline \multirow{3}{*}{$\mathrm{PH}$} & \multicolumn{4}{|c|}{ Dehulled } & \multicolumn{4}{|c|}{ Roasted } & \multicolumn{4}{|c|}{ Dehulled } & \multicolumn{4}{|c|}{ Roasted } \\
\hline & \multicolumn{4}{|c|}{$\begin{array}{l}\text { Storage time } \\
\text { (hours) }\end{array}$} & \multicolumn{4}{|c|}{$\begin{array}{l}\text { Storage time } \\
\text { (hours) }\end{array}$} & \multicolumn{4}{|c|}{$\begin{array}{l}\text { Storage time } \\
\text { (hours) }\end{array}$} & \multicolumn{4}{|c|}{$\begin{array}{l}\text { Storage time } \\
\text { (hours) }\end{array}$} \\
\hline & 1 & 2 & 24 & 48 & 1 & 2 & 24 & 48 & 1 & 2 & 24 & 48 & 1 & 2 & 24 & 48 \\
\hline 2 & 0 & 0 & 0 & 0 & 0 & 0 & 0 & 0 & 0 & 0 & 0 & 0 & 1 & 2 & 24 & 48 \\
\hline 4 & 8.0 & 8.2 & 8.3 & 8.3 & 8.0 & 8.2, & 8.3 & 8.3 & 8.0 & 8.2 & 8.3 & 8.3 & 0 & 0 & 0 & 0 \\
\hline 6 & 30 & 32 & 33 & 33 & 30 & 32 & 33 & 33 & 33 & 34 & 34 & 35 & 8.0 & 8.2, & 8.3 & 8.3 \\
\hline 8 & 0 & 0 & 0 & 0 & 41 & 50 & 51 & 52 & 0 & 0 & 0 & 0 & 30 & 32 & 33 & 33 \\
\hline 10 & 0 & 0 & 0 & 0 & 41 & 52 & 53 & 53 & 0 & 0 & 0 & 0 & 41 & 50 & 51 & 52 \\
\hline
\end{tabular}

*Emulsion stability expressed as volume $(\mathrm{ml})$ of water separated from the emulsion at room temperature.

** 1 and 2 refers to the first and second producers.

\section{Sesame seeds oil quality}

The results reported in table 6 show that the roasting process did not affect PV and the acidity of the extracted oil. These results disagree with those of Manal and Hassan [26] who reported that the roasting process for sesame seeds $\left(200^{\circ} \mathrm{C}\right.$ for $\left.15 \mathrm{~min}\right)$ resulted in an increase in PV and in the acidity of their oils.
Table 6. Effect of roasting of sesame seeds roasting on PV and Acidity of its oil

\begin{tabular}{|l|l|l|}
\hline Parameter & Dehlled & Roasted \\
\hline PV (Meq O2/kg oil) & $\mathrm{ND}^{*}$ & $\mathrm{ND}$ \\
\hline Acidity\% (as oleic acid) & $1.9 \pm 0.0 .5$ & $1.8 \pm 0.1$ \\
\hline
\end{tabular}

*ND: not detected

\section{Conclusion}

Based on the results obtained in this study, it can be concluded that hulls of sesame seeds contain polyphenols. Roasting or dehulling seeds at $130^{\circ} \mathrm{C}$ for 2 hours decreased poly phenol content. Although, polyphenol decreased due to roasting, they exhibited good antioxidant activity. Production of tahina and halawa increased polyphenols content, but decreased antioxidant activity. Roasting had no significant effect on the oxidation of fat of sesame seeds based on fatty acid composition and peroxide value. Roasting negatively affected both emulsion capacity and emulsion stability except at $\mathrm{pH} 2$ (where emulsion capacity and stability increased). Roasting positively affected both water and oil absorption capacity.

\section{References}

1. Namiki M. The chemistry and physicological functions on sesame. Food Rev Int. 1995; 11(2): 281-329. doi: 10.1080/87559129509541043

2. Kapoor LD. Hand Book of Ayurvedic Medicinal Plants, Herbal Reference Library. 1st Edition. New York: CRC Press. 2001.

3. Chen PR, Chien LK, Su TC, et al. Diatery sesame reduces serum cholestero and enhances antioxidant capacity in hypercholesterolemia. Nutr Res. 2005; 25(6): 5595-6754. doi: 10.1016/j.nutres.2005.05.007

4. Lazarou D, Grougnet R, Papadopoulos A. Antimutagenic properties of a polyphenols-enriched extract derived from sesame seed perisperm. Mutat Res. 2007; 634(1-2): 163-171. doi: 10.1016/j.mrgentox.2007.07.008

5. Zhao J, Liud D, Chen F, Liu G. Functional properties of sesame seed protein prepared by two different methods. J Chem Soc Pak. 2012; 34(5): 11011106.

6. Elleuch M, Besbes S, Roiseux O, Blecker C, Attia H. Quality characteristics of sesame seeds and by products. Food Chem. 2007; 103(2): 641-650. doi: 10.1016/j.foodchem.2006.09.008

7. Lee J, Lee $Y$, Choe E. Effects of sesamol, sesamin, and sesamolin extracted from roasted sesame oil on the thermal oxidation of methyl linoleate. LWT Food Sci Tech. 2007; 41(10): 1871-1875. doi: 10.1016/j.Iwt.2007.11.019

8. Johnson LA, Suleiman TM, Lusas EW. Sesame protein: a review and prospectus. J Am Oil Chem Soc. 1979; 56(3): 463-468. doi: 10.1007/ BF02671542

9. Rivas RN, Dench JE, Caygill JC. Nitrogen extractability of sesame (Sesamum indicum L.) seed and the preparation of two protein isolates. J Science Food Agric. 1981; 32(6): 565-571. doi: 10.1002/jsfa.2740320607

10. Onsaard E, Pomsamud P, Audtum P. Functional properties of sesame protein concentrates from sesame meal. Asian J Food Agro Indu. 2010; 3(4): 420-431.

11. Jeong SM, Kim SY, Kim DR, Nam KC, Ahn DU, Lee SC. Effect of roasting condition on antioxidant of defatted sesame meal. J Food Sci. 2004; 69(5): 5-10. doi: 10.1111/j.1365-2621.2004.tb10701.x

12. Kaur C, Kapoor C. Antioxidant activity and total phenolic content of some Asian vegetables. Int J Food Sci Tech. 2002; 37(2): 153-161. doi: 10.1046/j.1365-2621.2002.00552.x

13. Hatano T, Cagawa H, Yasuhara T, Okuda T. Two new flavonoids and other constituents in licorice root; their relative astringency and radical 
scavenging effects. Chem Pharm Bull. 1988; 36(6): 2090-2097. doi: 10.1248/cpb.36.2090

14. Sosulski A, Mccurdy F. Functionality of flours, protein fractions and isolates from field peas and faba bean. J Food Sci. 1987; 52(4): 1010-1014. doi: 10.1111/j.1365-2621.1987.tb14263.x

15. Marshall WH, Duston TR, Carpenter ZL, Smith C. A simple method of emulsion endpoint determination. J Food Sci. 1975; 40(4): 896-901. doi: 10.1111/j.1365-2621.1975.tb00587.x

16. Beuchat L. Functional and electrophoretic characteristics of succinylated peanut flour protein. J Agr Food Chem. 1977; 25(2): 258-263. doi: 10.1021/ jf60210a044

17. AOAC. Official Methods of Analysis. 18th edition. Association of Official Analytical Chemists. Washington D.C, USA. 2011.

18. Hassan MAM. Studies on Egyptian sesame seeds (Sesamum indicum L.) and its products 1 - Physicochemical analysis and phenolic acids of roasted Egyptian sesame seeds (Sesamum indicum L.). World J Dairy Food Sci. 2012; 7(2): 195-201

19. Hassan MAM. Studies on Egyptian Sesame Seeds (Sesamum indicum L) and Its products, effect of roasting conditions on peroxide value, free acidity, iodine value and antioxidant activity of sesame seeds. World J Dairy Food Sci. 2013; 8(1): 11-17.

20. 3Uzun B, Ülger S, Çagirgan Ml. Comparison of determinate and indeterminate types of sesame for oil content and fatty acid composition. Turk J Agric For. 2002; 26: 269-274.

21. Weiss EA. Sesame. In: Weiss EA (ed). Oilseed Crops. Longman Inc., New York. 1983.

22. Yokota $T$, Matsuzaki $Y$, Koyama $M$, et al. Sesamin, a lignan of sesame, down regulates cyclin DL protein expression in human tumor cells. Cancer Sci. 2007; 98(9): 1447-1453. doi: 10.1111/j.1349-7006.2007.00560.x
23. SAS 2000. SAS/version 7 softwar. SAS Institute Cary, NC.

24. Rizki $H$, Kzaiber $F$, Elharfi $M$, Ennahli $S$, Hanine $H$. Effects of roasting temperature and time on the physiochemical properties of sesame. Int $\mathrm{J}$ Innov Appl Stud. 2015; 11: 148-155.

25. Rizki $H$, Kzaiber F, Nablousi A, Elharfi M, Ennahli S, et al. Effect of microwave roasting on the oxidative stability and physiochemical properties of sesame seeds (Sesamum indicum). International Journal of Advanced Research in Science, Engineering and Technology. 2015; 2(2): 392-397.

26. Iqbal S, Bhanger Ml, Akhatar M, Anwar F, Ahmed KR, Anwer T. Antioxidant properties of methanolic extracts from leaves of Rhazyastricta. J Med Food. 2006; 9(2): 270-275. doi: 10.1089/jmf.2006.9.270

27. Kanu JP, Kerui Z, Ming HZ, Haifeng Q, Kanu J, Kexue Z. Functional properties of sesame (sesamum indicum $\mathrm{L}$ ) protein isolate as Influenced by $\mathrm{pH}$, temperature, Time, and Ratio of flour to water during its production. Asian J Biochem. 2007; 2(5): 289-301. doi: 10.3923/ ajb.2007.289.301

28. Ogunwolu SO, Henshaw FO, Mock HP, Santors A. Functional properties of protein concentrates and isolates produced from cashew (Anacardium occidentale L.) nut. Food Chem. 2009; 115(3): 852-858. doi: 10.1016/j. foodchem.2009.01.011

29. Khalid EK, Babiker EE, El Tinay AH. Solubility and functional properties of sesame seed proteins as influenced by $\mathrm{pH}$ and/or salt concentration. Food Chem. 2003; 82(3): 361-366. doi: 10.1016/S0308-8146(02)00555-1 